\title{
The Mediating Role of Knowledge Management and the Moderating Part of Organizational Culture between HRM Practices and Organizational Performance
}

\author{
Ahmad A. Al-Tit ${ }^{1}$ \\ ${ }^{1}$ Business Administration Department, College of Business \& Economics (CBE), Qassim University, Kingdom of \\ Saudi Arabia \\ Correspondence: Ahmad A. Al-Tit, Business Administration Department, College of Business \& Economics (CBE), \\ Qassim University, Kingdom of Saudi Arabia. E-mail: aa.altit@qu.edu.sa; ahmteet@yahoo.com
}

Received: October 9, 2015

Accepted: October 21, 2015

Online Published: December 25, 2015

doi: 10.5539/ibr.v9n1p43

URL: http://dx.doi.org/10.5539/ibr.v9n1p43

\begin{abstract}
The aim of this study was to investigate the relationship between human resource management (HRM) practices and organizational performance on the basis of 247 valid and reliable questionnaires distributed to managers at different management levels working in Jordanian manufacturing firms. The study also aimed to explore the mediating role of knowledge management as well as the moderating effect of organizational culture on the relationship between HRM practices and organizational performance. Ten HRM practices and 10 indicators of organizational performance were adopted for the purpose of this study. Knowledge management was measured by examining three processes; knowledge creation, sharing and utilization. Organizational culture was measured according to passive/defensive, aggressive/defensive and constructive cultures. The results of the study supported the presumed hypotheses. Hence, HRM practices significantly predicted organizational performance. Knowledge management mediated the relationship between HRM practices and organizational performance. Finally, it was found that organizational culture moderated the relationship between HRM practices and organizational performance as well as the relationship between HRM practices and knowledge management. Constructive cultures play a positive role in the relationship between HRM practices and organizational performance (OP), while defensive cultures negatively affect the relationship between HRM practices and knowledge management (KM). The main contribution of this study to the literature on HRM, KM and OP derives from the lack of prior studies addressing the same purposes as this study. The study informs researchers and managers that both knowledge management and organizational culture mediate and moderate the impact of HRM practices on organizational performance to a considerable extent.
\end{abstract}

Keywords: human resource management, organizational performance, knowledge management, organizational culture, Jordan

\section{Introduction}

In line with the literature on human resource management (HRM), knowledge management (KM), organizational culture (OC) and organizational performance (OP), it can be argued that HRM practices, KM practices and OC dimensions have numerous positive organizational influences underpinning OP. Consequently, this study brought the four constructs together to examine the relationships between them, particularly in the absence of similar studies conducted in Jordan. Jordanian organizations, whether public or private, need to dedicate more attention to HRM practices (Aladwan, Bhanugopan, \& Fish, 2014).

On the strength of this conclusion and considering the mediating role of KM in the relationship between HRM practices and OP (Patil \& Kant, 2012), as well as the moderating role of OC in the relationship between HRM practices, KM and OP (Chang \& Lin, 2015; Rai, 2011; Tong \& Mitra, 2009; Wang, Su, \& Yang, 2011), the purpose of this study is fourfold. First, it aims to examine the relationship between HRM practices and OP. Second, it predicts the influence of HRM practices on KM as well as the influence of KM on OP. Third, it explores whether both HRM and OC are significantly related to KM or not. Finally, it investigates the association between HRM, KM and OP.

Many studies have examined the relationship between HRM practices and OP and have provided support for the assumption that HRM practices significantly predict OP (Amin, Ismail, Rasid, \& Selemani, 2014; Chan \& Mak, 2012; 
Chand \& Katou, 2007; Osman, Ho, \& Galang, 2011). The same thing can be said of the relationship between HRM practices and KM (Andreeva \& Kianto, 2012; Donate \& Guadamillas, 2011; Kuo, 2011; Patil \& Kant, 2012; Theriou $\&$ Chatzoglou, 2014).

On the relationship between KM practices and OP, mixed results have been found. Some studies have found that KM practices improve OP (Darroch, 2005; Gharakhani \& Mousakhani, 2012; Kuo, 2011; Marqués \& Simón, 2011; Mills \& Smith, 2011; Shehata, 2015; Valmohammadi \& Ahmadi, 2015; Zack, McKeen, \& Singh, 2009), whereas others have found only slight enhancements in OP (Wu \& Chen, 2014). Furthermore, the part played by OC in the relationships between the above variables has been well documented (Chang \& Lin, 2015; Kuo, 2011; Mahmoudsalehi \& Moradkhannejad, 2012; Rai, 2011; Theriou \& Chatzoglou, 2008; Tseng, 2010; Tong \& Mitra, 2009; Syed-Ikhsan \& Rowland, 2004; Wang et al., 2011).

\section{Literature Review and Research Hypotheses}

\subsection{Human Resource Management}

Human Resource Management is the effective utilization of people within an organization to achieve organizational goals (Fong, Ooi, Lee, \& Chong, 2011; Al-Tit, 2014). Chiang, Han, and Chuang (2011) pictured HRM as people management. There is abundant literature on HRM practices and several categorizations have been proposed. Chiang et al. (2011) examined the relationship between HRM practices and KM and divided HRM practices into low-cost and high-commitment practices, with process efficiency and cost reduction being the main focus of low-cost practices and high-commitment practices being aimed at increasing employee commitment and motivation. In her study on the relationship between HRM practices and KM, Edvardsson (2008) identified four types of HRM practices: Recruitment and selection, training and development, performance management and reward and recognition. On the other hand, Theriou and Chatzoglou (2008) listed a number of optimal HRM practices that can be applied to enhance OP: Extensive training, career opportunities, clearly described jobs, teamwork, performance-based compensation, decentralized decision making, recruitment and selection, involvement and communication, and status with limited differences. In addition, the best HRM practices have a pivotal role in KM practices, such as the creation, absorption, transfer and sharing of knowledge.

\subsection{Organizational Performance}

Organizational Performance is a measure that assesses the efficiency and effectiveness of an organization striving to achieve its organizational goals (Ho, 2008; Al-Tit \& Hunitie, 2015). Several methods have been suggested for measuring OP, which can be categorized into two types: Financial and non-financial indicators. Sharabati, Jawad, and Bontis (2010) evaluated the business performance of Jordanian pharmaceutical firms using productivity, profitability and market valuation. Chong et al. (2011) studied the relationship between supply chain management and organizational and innovation performance and used product return or rejection, sales, cost reduction, customer satisfaction, inventory turnover and lead time to measure OP. Lee and Yu (2004) evaluated OP based on the industry. They used profitability, return on assets and sales turnover for industrial firms. In contrast, the OP of insurance companies was assessed by return on investment and business growth rate. Finally, hospitals' OP was evaluated applying rates of bed occupation and patients' length of stay.

\subsection{Knowledge Management}

Strategies that can be used to create, protect and use knowledge assets are deemed to constitute Knowledge Management (Mahmoudsalehi et al., 2012). The ultimate purpose of KM practices is to improve the efficiency and effectiveness of the exploitation of knowledge assets (Inkinen, Kianto, \& Vanhala, 2015). Chang and Lin (2015) identified four dimensions of KM: Knowledge creation, storage, transfer and application. Wu and Chen (2014) assessing the contribution of KM to OP, used four KM practices: Creation, transfer, integration and application. Studying the moderating role of the KM process on the relationship between training and organizational effectiveness, Abd Rahman, Ng, Sambasivan, and Wong (2013) used four dimensions of the KM process: Knowledge acquisition, application, conversion and protection. Ho (2009) mentioned five dimensions of KM, namely creating, accumulating, sharing, utilizing and internalizing knowledge. Investigating the relationship between KM and OP, Hsiao, Chen, and Chang (2011) adopted two dimensions to assess KM capacity comprising the acquisition and dissemination of knowledge.

\subsection{Organizational Culture}

Organizational culture is defined as a set of shared beliefs, values and assumptions that shape the perceptions and reactions of a group of people within an organization regarding events in their own environment (Anantatmula, 2010; Chang \& Lin, 2015; Mahmoudsalehi et al., 2012; Yiing \& Bin Ahmad, 2009). In the KM context, Chang and Lin (2015) divided OC styles into five cultures: Process-versus result-oriented, tightly versus loosely controlled, 
employee-versus job-oriented, open versus closed systems, and parochial versus professionally oriented cultures. According to Corbett and Rastrick (2000), OC consists of three dimensions of culture, i.e. passive (PC), aggressive (AC) and constructive (CC). These constructs were adopted in this study. The significance of studying the moderating role of OC in this research is derived from Kreitner and Kinicki (2004, cited in Maheshwari \& Vohra, 2015), who supposed OC to be an important inducement of OP, and from Chang and Lin (2015), who took OC to be a key factor in the success of KM. Ho (2009) stated that culture is one of four KM enablers. In a work aimed at investigating the relationships between OC, environmental responsiveness capability and KM, Akhavan, Sanjaghi, Rezaeenour and Ojaghi (2014) employed four dimensions of KM: Knowledge creation and acquisition, organization and saving, dissemination and sharing, and knowledge application.

\subsection{Human Resource Management and Organizational Performance}

There is a well-documented and established linkage between HRM practices and OP. Collecting data from top and middle managers working in 78 companies in Oman, Moideenkutty, Al-Lamki and Murthy (2011) examined the ability of high-involvement HRM practices to predict OP. They found that high-involvement HRM practices, namely selective staffing, extensive training, empowerment and performance management, are significantly linked to OP when evaluated by the market-to-book value ratio. Amin et al. (2014) explored the impact of seven HRM practices (career planning, compensation, employee participation, job definition, performance appraisal, recruitment and training) on OP. Using a questionnaire-based survey consisting of 46 items to collect data from 300 employees working at a public university in Malaysia, the regression analysis results revealed a positive effect of such practices on OP. Osman et al. (2011) explored the impact of compensation, HR planning, job design, job health and safety, performance appraisal, staffing and training on OP through a questionnaire targeting HR managers and CEOs from different industries in Malaysia. A total of 271 questionnaires were analysed. Their results indicated that around 50\% of a firm's OP could be traced back to the effective use of HRM practices.

Chand and Katou (2007) conducted a study to investigate the impact of HRM practices on OP in the Indian hotel industry. They found a positive relationship between HR practices (job design, manpower planning, quality circles, recruitment and selection, training and development, and pay systems) and hotels' OP. High-performance HRM practices (careful selection, enhanced jobs, extensive training, high payments, information sharing and performance feedback) were presumed by Chan and Mak (2012) to have a significant impact on OP. Gathering data from 227 HRM employees in four industries (finance, insurance, manufacturing and real estate) in Hong Kong, they confirmed that high-performance HRM practices are positively correlated to OP. Contrary to the above findings, Kuo (2011) revealed a non-significant direct relationship between HRM practices and OP. but an indirect relationship mediated through three constructs; organizational learning $(\mathrm{OL})$, organizational innovation $(\mathrm{OI})$ and $\mathrm{KM}$. The aim of Theriou and Chatzoglou's (2008) study was twofold: (i) To examine the relationships between HRM, KM, OL and OC; (ii) to investigate the impact of these constructs on OP. Their contribution indicated that HRM affects both KM and OL, thus shaping OC, which in turn results in improved performance.

\subsection{Human Resource Management and Knowledge Management}

Patil and Kant (2012) indicated that KM processes (i.e. knowledge accumulation, knowledge sharing and knowledge utilization) mediate the relationship between HR strategy (education and training, rewards and incentives, employee empowerment, open communication, employee involvement and workforce flexibility) and OP. Andreeva and Kianto (2012) tested a model consisting of four variables-HR practices for KM, information communication technology (ICT), competitiveness and financial performance-to investigate links between these constructs. Regarding one of the suggested relationships, i.e. the relationship between HR practices and KM and OP, the results highlighted a positive influence of these practices on OP. Theriou and Chatzoglou (2014) examined the effect of best practices in HRM (compensation and incentives, contingent on performance, employee health and safety, employee involvement, internal communication arrangements, extensive training, harmonization, internal career opportunities, job descriptions, selective hiring, use of teams and decentralization) on KM, using a sample comprising a total of $212 \mathrm{HR}$ managers operating in the Greek manufacturing industries. With respect to the relationship between HRM practices and KM, the results supported the hypothesis that best practices in HRM positively affect KM. Kuo (2011) confirmed the positive impact of HRM practices (employee participation, performance appraisal, reward and compensation, staffing, training and development) on KM (knowledge creation and improvement, knowledge learning and acquisition and knowledge sharing). Studying companies from the Spanish industrial sector, Donate and Guadamillas (2011) found support for the hypothesis of a relationship between knowledge-related HR practices, knowledge exploration practices and innovation, but not for a relationship between knowledge-related HR practices, knowledge exploitation practices and innovation. 


\subsection{Knowledge Management and Organizational Performance}

Nold (2012) attributed the outperformance of a firm to the nature of its KM systems. Shehata (2015) examined the impact of KM systems (knowledge creation, acquisition, codification, sharing and transfer and measurement) on firms' $\mathrm{OP}$ in the Egyptian information technology and communication industry. The results emphasized the positive relationship between KM and OP. Gharakhani and Mousakhani (2012) found a significant impact from three dimensions of KM on the OP of small and medium enterprises. In their 2006 study on 222 companies in the Spanish biotechnology and telecommunications industries, Marqués and Simón (2011) verified the positive relationship between KM and OP. Concurrently, Kuo (2011) accepted the assumed positive influence of KM on OP. The expectation of Zack et al. (2009) concerning a direct association between KM practices and OP was supported through the analysis of data from companies in different industries in Canada, the USA and Australia.

In South Africa, Kruger and Johnson (2011) explored the relationship between KM maturity (i.e. knowledge capture, knowledge exchange, knowledge internalization and knowledge re-use) and OP (customer satisfaction, employee satisfaction, growth, intangible value, leverage, liquidity, profitability and shareholder satisfaction). In Jamaica, Mills and Smith (2011) distributed 500 questionnaires to managers from the manufacturing and services sectors with the aim of investigating the relationship between KM and OP. The hypotheses that knowledge acquisition, knowledge application and knowledge protection are related to OP were accepted. However, knowledge conversion (KC) had no impact on OP. Kalling (2003) argued that the KM-OP relationship not only depends on knowledge but also on knowledge utilization and capitalization. In New Zealand, Darroch (2005) provided evidence supporting the hypothesis that the effective use of $\mathrm{KM}$ is positively related to superior financial performance.

\subsection{Organizational Culture and Knowledge Management}

Culture is supposed to be one of the most important critical success factors that affect KM (Mahmoudsalehi et al., 2012). The relationship between OC and Knowledge Conversion (KC) (knowledge socialization, knowledge externalization, combination and internalization) was examined by Tseng (2010) and the results supported the significant impacts of differences in OC on KM. However, OC may play a limited role in KM practice. The findings of Chang and Lin (2015) indicated that both job-oriented and results-oriented cultures are positively related to the KM process, but restricted (rules-based) cultures are not. Pyöriä (2007) highlighted the significance of informal OC dimensions for knowledge workers' performance. Rai (2011) studied the relationship between OC and KM and indicated a significant impact of OC on the behaviour of tacit knowledge sharing. Concurrently, Wang et al. (2011) found a critical role for OC in knowledge creation capability. Tong and Mitra (2009) conducted a case study with a Chinese mobile phone company to examine the impact of OC on KM practices. Their results showed an important linkage between OC and KM. The correlation between a total of 44 OC attributes and KM implementation and sharing was validated by Park, Ribiére and Schulte (2004) using a sample of 26 US companies. The results of Syed-Ikhsan and Rowland's (2004) study revealed a significant positive relationship between a sharing culture and knowledge transfer, as well as knowledge assets. Akhavan et al. (2014) cited dual effects of OC on KM success. By virtue of the literature reviewed, the following hypotheses were developed.

$\mathrm{H}_{1}$ : HRM practices predict OP.

$\mathrm{H}_{2}$ : HRM practices predict KM.

$\mathrm{H}_{3}$ : KM predicts OP.

$\mathrm{H}_{4}$ : HRM practices and $\mathrm{OC}$ are related to $\mathrm{KM}$.

$\mathrm{H}_{5}$ : HRM practices and $\mathrm{KM}$ are related to OP.

\section{Conceptual Model}

Figure 1 depicts the conceptual model of the research. It illustrates the relationships between the five hypotheses and each variable. According to the figure, there is a relationship between the predictor variable (HRM) and the response variable (OP). KM mediates the relationship between these two constructs; hence, HRM is related to KM and KM is related to OP. On the other hand, OC moderates the relationship between HRM and OP and the relationship between HRM and KM. All relationships are expected to be positive, except the moderating role of OC in the relationship between HRM and KM. An expanded version of the conceptual model can be seen in Figure 2. 


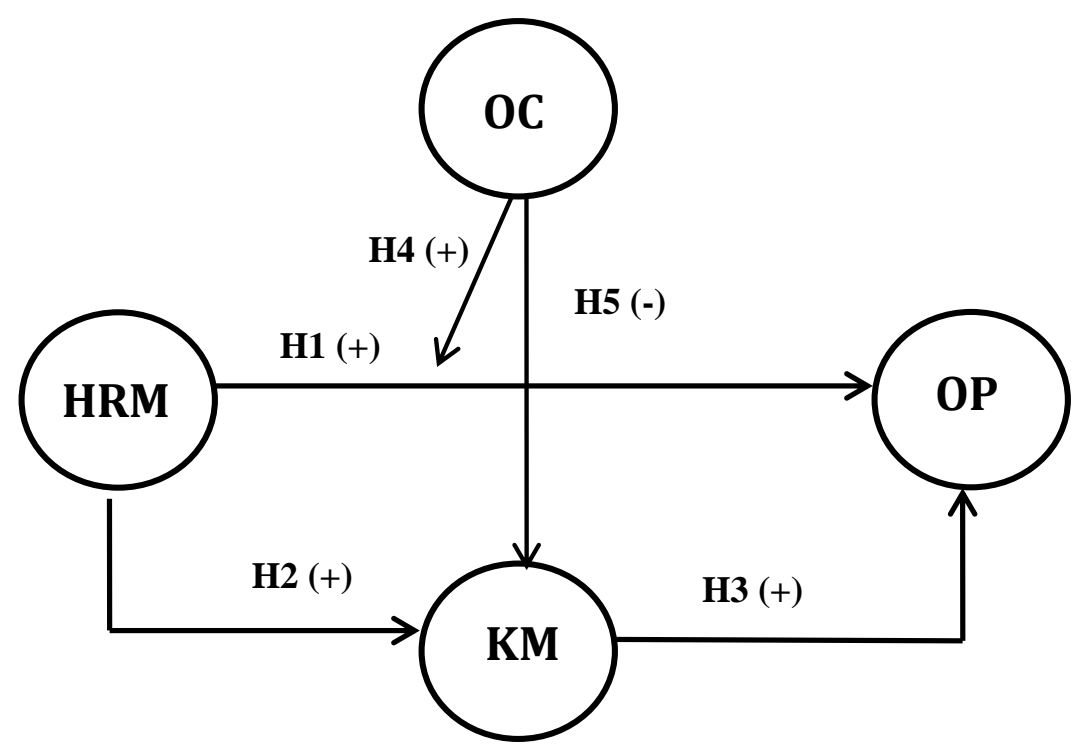

Figure 1. Research conceptual model

\section{Research Methodology}

\subsection{Research Sample and Data Collection}

Industrial Jordanian firms constituted the frame for the population of the study. A sample of 60 firms was randomly selected and a total of 300 questionnaires were sent via email to managers at different management levels. Only 57 questionnaires were returned. Accordingly, questionnaires were administered again by hand to around 235 managers. The two rounds yielded 247 valid questionnaires for analysis.

\subsection{Measures}

To evaluate HRM practices, a total of 10 best practices were adopted on the basis of prior research (Cai \& Kleiner, 2004; González, 2004; Hashim, 2010; Moideenkutty et al., 2011; Ortega-Parra \& Sastre-Castillo, 2013; Rowden, 2002; Tan \& Nasurdin, 2011; Zairi, 1998): Employment security (ES), selective staffing (SS), extensive training (ET), performance evaluation (PE), information sharing (IS), incentives (IN), promotions (PR), empowerment (EM), career management (CM) and employees' health and safety (HS) (Chan \& Mak, 2012).

For OP, 10 financial and non-financial indicators were adopted: operational excellence (OE), customer intimacy (CI) (Wu \& Chen, 2014), high quality (HQ), employee satisfaction (SA) (Tseng \& Lee, 2014), staff turnover rates (ST) (Lee \& Yu, 2004), market share (MS) (Felício, Couto, \& Caiado, 2014), internal processes (IP), learning \& growth (LG) (Salehzadeh, Pool, Lashaki, Dolati, \& Jamkhaneh, 2015), profitability (PF) and growth of sales (GS) (Lopez-Rodriguez, 2009). The participants were asked to rate their organization in terms of these indicators. The results of this study were built on the aggregate performance level.

Concerning KM appraisal, three dimensions were used: knowledge creation (CR), sharing (SH) and utilization (UT) (Abd Rahman et al., 2013; Chang \& Lin, 2015; Ho, 2009; Wu \& Chen, 2014).

Finally, the Organizational Culture Inventory (OCI), developed by Cooke and Lafferty (1983), was used to measure OC. According to Corbett and Rastrick (2000), the OCI covers three dimensions of OC: passive/defensive (PD), aggressive/defensive (AD) and constructive (CO). Moreover, Balthazard, Cooke, and Potter (2006) note that the OCI measures 12 sets of behavioural norms. The PD dimension can be distinguished in terms of approval, conventional, dependent and avoidance cultures. The AD dimension is characterized by oppositional, power, competitive and perfectionist cultures. The $\mathrm{CO}$ dimension represents achievement, self-actualizing, encouraging and affiliative cultures.

\section{Data Analysis and Results}

\subsection{Validity and Reliability}

The validity of the constructs was established using the comparative fit index (CFI) and the root mean square error of approximation (RMSEA) and fit indices such as $\chi^{2} / d f$ (Al-Tit \& Nakhleh, 2014). The reliability of the constructs was confirmed using Cronbach's alpha coefficient $(\alpha)$. The results of aforesaid analysis indicated valid and reliable measurements, with $\chi^{2} / d f$ less than 2, CFI above 0.90, RMSEA less than 0.08 and $\alpha=0.784$. 


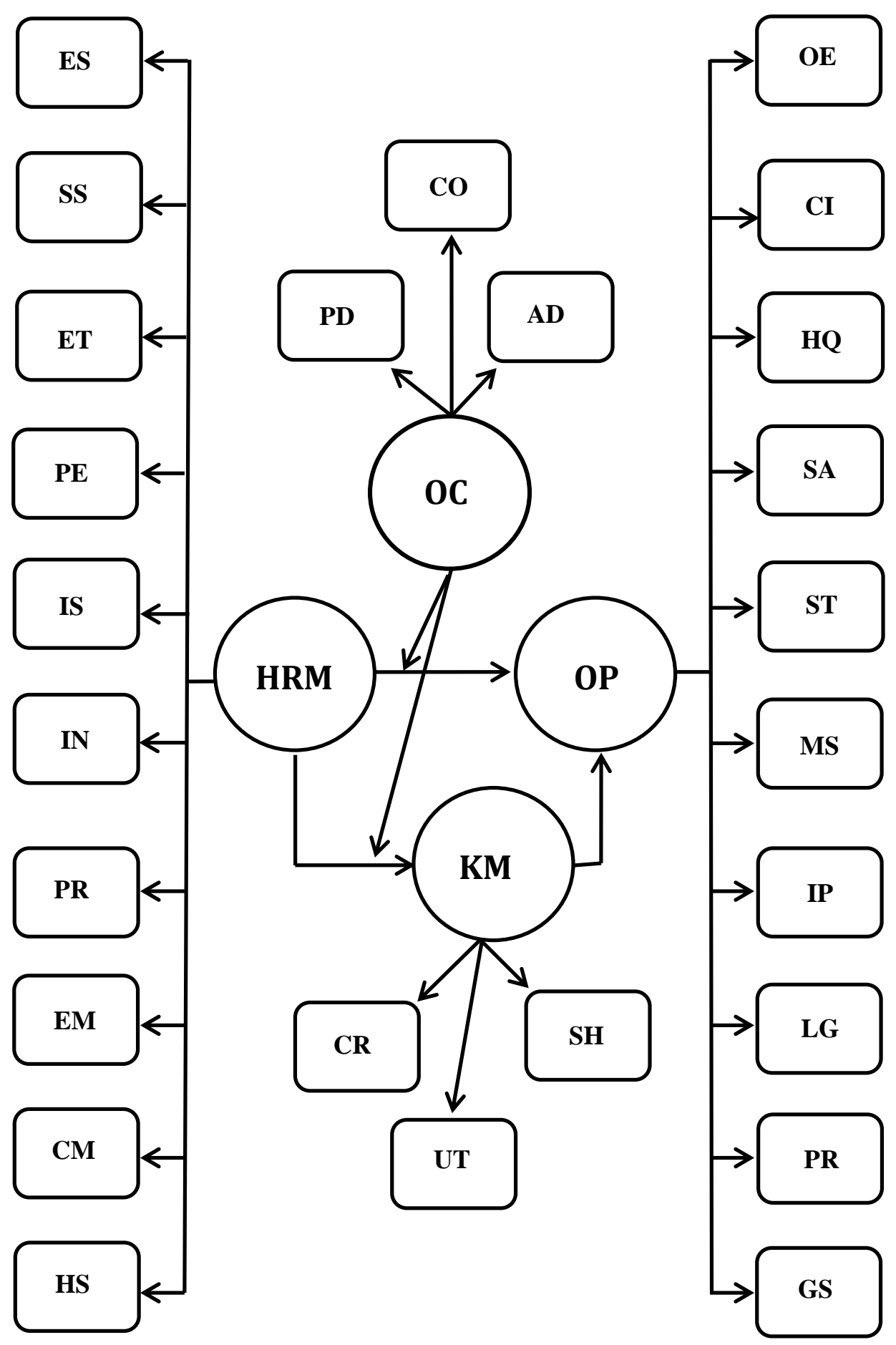

Figure 2. Expanded research conceptual model

\subsection{Inter-Correlation Matrix}

The results of the correlations among the research variables shown in Table 1 indicate that HRM practices, KM processes, OC dimensions and OP indicators are related to each other. In addition, all HRM practices are significantly related to $\mathrm{KM}$ processes and $\mathrm{OP}$ indicators. Also, all $\mathrm{KM}$ processes are related to OP. 
Table 1. Correlations

\begin{tabular}{|c|c|c|c|c|c|c|c|c|c|c|c|c|c|c|c|c|c|c|c|c|c|c|c|c|c|c|}
\hline \multicolumn{27}{|c|}{ Table 1. Correlation Matrix } \\
\hline $\mathrm{CO}$ & & & & & & & & & & & & & & & & & & & & & & & & & & - \\
\hline $\mathrm{AD}$ & & & & & & & & & & & & & & & & & & & & & & & & & - & 0.42 \\
\hline PD & & & & & & & & & & & & & & & & & & & & & & & & - & 0.41 & 0.32 \\
\hline GS & & & & & & & & & & & & & & & & & & & & & & & - & 0.71 & 0.68 & 0.50 \\
\hline $\mathrm{PF}$ & & & & & & & & & & & & & & & & & & & & & & - & 0.42 & 0.64 & 0.56 & 0.69 \\
\hline LG & & & & & & & & & & & & & & & & & & & & & - & 0.31 & 0.42 & 0.41 & 0.47 & 0.54 \\
\hline $\mathrm{IP}$ & & & & & & & & & & & & & & & & & & & & - & 0.41 & 0.56 & 0.53 & 0.61 & 0.64 & 0.47 \\
\hline MS & & & & & & & & & & & & & & & & & & & - & 0.53 & 0.32 & 0.43 & 0.40 & 0.34 & 0.51 & 0.64 \\
\hline ST & & & & & & & & & & & & & & & & & & - & 0.50 & 0.41 & 0.30 & 0.52 & 0.49 & 0.58 & 0.66 & 0.51 \\
\hline SA & & & & & & & & & & & & & & & & & - & 0.42 & 0.50 & 0.41 & 0.36 & 0.50 & 0.63 & 0.65 & 0.41 & 0.67 \\
\hline HQ & & & & & & & & & & & & & & & & - & 0.55 & 0.52 & 0.34 & 0.65 & 0.44 & 0.64 & 0.52 & 0.71 & 0.53 & 0.55 \\
\hline $\mathrm{CI}$ & & & & & & & & & & & & & & & - & 0.52 & 0.61 & 0.33 & 0.45 & .62 & 0.41 & 0.39 & 0.40 & 0.35 & 0.42 & 0.47 \\
\hline $\mathrm{OE}$ & & & & & & & & & & & & & & - & 0.35 & 0.69 & 0.67 & 0.66 & 0.75 & 0.79 & 0.77 & 0.61 & 0.68 & 0.61 & 0.56 & 0.58 \\
\hline UT & & & & & & & & & & & & & - & 0.76 & 0.61 & 0.83 & 0.51 & 0.61 & 0.73 & 0.72 & 0.75 & 0.77 & 0.68 & 0.47 & 0.77 & 0.65 \\
\hline $\mathrm{SH}$ & & & & & & & & & & & & - & 0.73 & 0.71 & 0.62 & 0.73 & 0.61 & 0.42 & 0.73 & 0.64 & 0.60 & 0.71 & 0.72 & 0.35 & 0.69 & 0.57 \\
\hline $\mathrm{CR}$ & & & & & & & & & & & - & 0.74 & 0.73 & 0.74 & 0.60 & 0.51 & 0.75 & 0.42 & 0.68 & 0.66 & 0.58 & 0.68 & 0.67 & 0.31 & 0.68 & 0.67 \\
\hline HS & & & & & & & & & & - & 0.68 & 0.51 & 0.62 & 0.61 & 0.64 & 0.71 & 0.63 & 0.41 & 0.35 & 0.36 & 0.59 & 0.64 & 0.54 & 0.33 & 0.51 & 0.55 \\
\hline $\mathrm{CM}$ & & & & & & & & & - & 0.51 & 0.59 & 0.64 & 0.69 & 0.61 & 0.54 & 0.73 & 0.66 & 0.61 & 0.68 & 0.64 & 0.69 & 0.67 & 0.65 & 0.36 & 0.55 & 0.61 \\
\hline EM & & & & & & & & - & 0.71 & 0.51 & 0.61 & 0.50 & 0.43 & 0.51 & 0.52 & 0.79 & 0.75 & 0.67 & 0.56 & 0.52 & 0.56 & 0.64 & 0.66 & 0.33 & 0.62 & 0.51 \\
\hline PR & & & & & & & - & 0.52 & 0.65 & 0.35 & 0.41 & 0.42 & 0.52 & 0.61 & 0.51 & 0.54 & 0.74 & 0.71 & 0.63 & 0.53 & 0.58 & 0.54 & 0.53 & 0.54 & 0.72 & 0.45 \\
\hline IN & & & & & & - & 0.66 & 0.61 & 0.55 & 0.45 & 0.66 & 0.67 & 0.59 & 0.77 & 0.69 & 0.75 & 0.80 & 0.67 & 0.68 & 0.74 & 0.58 & 0.66 & 0.68 & 0.44 & 0.64 & 0.61 \\
\hline IS & & & & & - & 0.68 & 0.55 & 0.53 & 0.45 & 0.36 & 0.64 & 0.71 & 0.78 & 0.61 & 0.54 & 0.59 & 0.61 & 0.41 & 0.42 & 0.68 & 0.72 & 0.63 & 0.30 & 0.51 & 0.54 & 0.72 \\
\hline $\mathrm{PE}$ & & & & - & 0.41 & 0.65 & 0.68 & 0.34 & 0.67 & 0.36 & 0.65 & 0.40 & 0.54 & 0.52 & 0.43 & 0.51 & 0.63 & 0.64 & 0.37 & 0.47 & 0.56 & 0.57 & 0.42 & 0.38 & 0.50 & 0.51 \\
\hline ET & & & - & 0.74 & 0.68 & 0.78 & 0.74 & 0.59 & 0.80 & 0.44 & 0.57 & 0.63 & 0.75 & 0.71 & 0.34 & 0.67 & 0.51 & 0.58 & 0.32 & 0.69 & 0.64 & 0.62 & 0.41 & 0.51 & 0.44 & 0.66 \\
\hline SS & & - & 0.31 & 0.58 & 0.43 & 0.70 & 0.47 & 0.59 & 0.38 & 0.49 & 0.69 & 0.52 & 0.60 & 0.44 & 0.53 & 0.40 & 0.67 & 0.56 & 0.49 & 0.43 & 0.72 & 0.61 & 0.61 & 0.46 & 0.35 & 0.51 \\
\hline \multirow[t]{2}{*}{ ES } & - & 0.44 & 0.51 & 0.43 & 0.38 & 0.47 & 0.41 & 0.52 & 0.61 & 0.42 & 0.43 & 0.41 & 0.54 & 0.50 & 0.46 & 0.39 & 0.37 & 0.58 & 0.32 & 0.49 & 0.56 & 0.44 & 0.64 & 0.32 & 0.39 & 0.44 \\
\hline & ES & SS & ET & PE & IS & IN & PR & EM & $\mathrm{CM}$ & HS & $\mathrm{CR}$ & SH & UT & $\mathrm{OE}$ & CI & $\mathrm{HQ}$ & SA & ST & MS & IP & LG & $\mathrm{PF}$ & GS & PD & $\mathrm{AD}$ & $\mathrm{CO}$ \\
\hline
\end{tabular}

\subsection{Hypotheses Testing}

Hypothesis 1 posited that HRM practices directly predict OP. Based on the results of multiple regression shown in Table 2, HRM practices explain $52 \%$ of variability in OP $\left(\mathrm{r}^{2}=0.518, \mathrm{f}=13.47, \mathrm{p}<0.05\right)$. From the regression coefficients it is apparent that SS is the most important practice in predicting OP $(\beta=0.561, \mathrm{t}=8.114, \mathrm{p}<0.05)$, followed by $\operatorname{ET}(\beta=0.396, \mathrm{t}=6.417, \mathrm{p}<0.05), \operatorname{PE}(\beta=0.392, \mathrm{t}=5.331, \mathrm{p}<0.05), \mathrm{IN}(\beta=0.387, \mathrm{t}=5.015, \mathrm{p}<$ 0.05), PR $(\beta=0.369, \mathrm{t}=4.813, \mathrm{p}<0.05), \mathrm{ES}(\beta=0.357, \mathrm{t}=4.601, \mathrm{p}<0.05), \operatorname{IS}(\beta=0.348, \mathrm{t}=4.517, \mathrm{p}<0.05)$, $\operatorname{EM}(\beta=0.341, \mathrm{t}=4.357, \mathrm{p}<0.05)$ and $\operatorname{HS}(\beta=0.328, \mathrm{t}=4.312, \mathrm{p}<0.05)$. CM was ranked last $(\beta=0.311, \mathrm{t}=$ $3.701, \mathrm{p}<0.05)$. Hence, hypothesis 1 is supported.

Hypothesis 2 suggested that HRM practices directly predict KM. The results of the regression analysis shown in Table 3 indicate that HRM practices explain $48 \%$ of variability in $\mathrm{KM}\left(\mathrm{r}^{2}=0.476, \mathrm{f}=11.86, \mathrm{p}<0.05\right)$. The beta coefficients show that IS is the most important practice in predicting $\mathrm{KM}(\beta=0.618, \mathrm{t}=11.40, \mathrm{p}<0.05)$, followed by ET $(\beta=0.577, \mathrm{t}=8.113, \mathrm{p}<0.05), \mathrm{IN}(\beta=0.517, \mathrm{t}=6.341, \mathrm{p}<0.05), \operatorname{EM}(\beta=0.419, \mathrm{t}=6.011, \mathrm{p}<0.05), \mathrm{SS}(\beta=$ $0.378, \mathrm{t}=4.351, \mathrm{p}<0.05), \operatorname{PR}(\beta=0.327, \mathrm{t}=4.201, \mathrm{p}<0.05), \operatorname{PE}(\beta=0.324, \mathrm{t}=4.117, \mathrm{p}<0.05), \operatorname{ES}(\beta=0.320, \mathrm{t}$ $=4.105, \mathrm{p}<0.05), \mathrm{CM}(\beta=0.309, \mathrm{t}=3.94, \mathrm{p}<0.05)$ and HS $(\beta=0.313, \mathrm{t}=3.287, \mathrm{p}<0.05)$. On the basis of these results, hypothesis 2 is accepted.

The relationship between $\mathrm{KM}$ and $\mathrm{OP}$ was hypothesized in $\mathrm{H}_{3}$. It was presumed that $\mathrm{KM}$ predicts $\mathrm{OP}$. The results of the regression analysis shown in Table 4 highlight a good explanatory power of KM (61\%) in the variability of OP. According to the results, knowledge utilization has the highest beta coefficient $(\beta=0.441, \mathrm{t}=6.471, \mathrm{p}<$ $0.05)$, followed by knowledge sharing $(\beta=0.410, \mathrm{t}=5.413, \mathrm{p}<0.05)$ and knowledge creation $(\beta=0.319, \mathrm{t}=$ $5.002, \mathrm{p}<0.05)$. Therefore, hypothesis 3 is accepted. 
Table 2. HRM practices and OP

\begin{tabular}{|c|c|c|c|c|c|c|c|c|c|c|}
\hline \multirow{3}{*}{$\begin{array}{c}\text { Model } \\
1 \\
\end{array}$} & \multicolumn{2}{|c|}{$\mathrm{r}$} & \multicolumn{2}{|c|}{$\mathrm{r}^{2}$} & \multicolumn{2}{|c|}{$\mathrm{f}$} & \multicolumn{2}{|c|}{$\mathrm{p}$} & \multirow[b]{3}{*}{$\mathrm{CM}$} & \multirow[b]{3}{*}{ HS } \\
\hline & \multicolumn{2}{|c|}{0.72} & \multicolumn{2}{|c|}{0.518} & \multicolumn{2}{|c|}{13.47} & \multicolumn{2}{|c|}{0.000} & & \\
\hline & ES & SS & ET & $\mathrm{PE}$ & IS & IN & PR & EM & & \\
\hline$\beta$ & 0.357 & 0.561 & 0.396 & 0.392 & 0.348 & 0.387 & 0.369 & 0.341 & 0.439 & 0.328 \\
\hline $\mathrm{t}$ & 4.601 & 8.114 & 6.417 & 5.331 & 4.517 & 5.015 & 4.813 & 4.357 & 3.701 & 4.312 \\
\hline $\mathrm{P}$ & 0.001 & 0.000 & 0.000 & 0.011 & 0.000 & 0.000 & 0.003 & 0.000 & 0.014 & 0.000 \\
\hline
\end{tabular}

Note. Independent variables: ES (employment security), SS (selective staffing), ET (extensive training), PE (performance evaluation), IS (information sharing), IN (incentives), PR (promotions), EM (employee empowerment), CM (career management), HS (employees' health and safety). Dependent variable: $\mathrm{OP}$.

Table 3. HRM practices and KM

\begin{tabular}{|c|c|c|c|c|c|c|c|c|c|c|}
\hline \multirow{3}{*}{ Model 1} & \multicolumn{2}{|c|}{$\mathrm{r}$} & \multicolumn{2}{|c|}{$r^{2}$} & \multicolumn{2}{|c|}{$\mathrm{f}$} & \multicolumn{2}{|c|}{$\mathrm{p}$} & \multirow[b]{3}{*}{$\mathrm{CM}$} & \multirow[b]{3}{*}{ HS } \\
\hline & \multicolumn{2}{|c|}{0.69} & \multicolumn{2}{|c|}{0.476} & \multicolumn{2}{|c|}{11.68} & \multicolumn{2}{|c|}{0.000} & & \\
\hline & ES & SS & ET & PE & IS & IN & PR & EM & & \\
\hline$\beta$ & 0.320 & 0.378 & 0.557 & 0.324 & 0.618 & 0.517 & 0.327 & 0.419 & 0.309 & 0.313 \\
\hline $\mathrm{t}$ & 4.105 & 4.361 & 8.113 & 4.117 & 11.40 & 6.341 & 4.201 & 6.011 & 3.940 & 3.287 \\
\hline $\mathrm{P}$ & 0.000 & 0.000 & 0.004 & 0.000 & 0.007 & 0.000 & 0.000 & 0.000 & 0.020 & 0.000 \\
\hline
\end{tabular}

Note. Independent variables: ES (employment security), SS (selective staffing), ET (extensive training), PE (performance evaluation), IS (information sharing), IN (incentives), PR (promotions), EM (employee empowerment), CM (career management), HS (employees' health and safety).

Dependent variable: KM.

Table 4. KM practices and OP

\begin{tabular}{ccccc}
\hline \multirow{2}{*}{ Model 1 } & $\mathrm{r}$ & $\mathrm{r}^{2}$ & $\mathrm{f}$ & $\mathrm{p}$ \\
\cline { 2 - 5 } & 0.78 & 0.608 & 14.28 & 0.000 \\
\hline & $\mathrm{KCR}$ & $\mathrm{SH}$ & $\mathrm{KUT}$ & \\
$\beta$ & 0.319 & 0.410 & 0.441 & \\
$\mathrm{t}$ & 5.002 & 5.413 & 6.471 & \\
$\mathrm{P}$ & 0.000 & 0.000 & 0.000 & \\
\hline
\end{tabular}

Note. Independent variables: knowledge creating (CR), sharing (SH) and utilizing (UT), Dependent variable: OP

Both hypotheses $\mathrm{H}_{4}$ and $\mathrm{H}_{5}$ are related to the moderating impact of OC. $\mathrm{H}_{4}$ suggested a positive impact of OC on the relationship between HRM practices and OP. On the other hand, $\mathrm{H}_{5}$ assumed a negative impact of OC on the relationship between HRM practices and MK. Two models were applied to test these hypotheses. In model 1, KM was the dependent variable. The results shown in Table 5 indicate that both HRM practices and OC are positively associated with KM. In addition, the interaction term between HRM practices and OC is significant ( $\beta$ $=-0.083, \mathrm{p}<0.05)$. In model 2 , OP was the dependent variable. It was found that HRM practices and KM are correlated with OP. The interaction term between HRM practices and OC is also significant $(\beta=0.118, \mathrm{p}<0.05)$. On the basis of these findings, the moderating effect of OC is established in this study.

Table 5. Results of OC moderating effects

\begin{tabular}{ccccc}
\hline & \multicolumn{2}{c}{ KM } & OP \\
\hline Variables & Step 1 & Step 2 & Step 1 & Step 2 \\
HRM practices & 0.431 & 0.422 & 0.231 & 0.224 \\
OC & 0.341 & 0.337 & 0.117 & 0.109 \\
KM & 0.284 & 0.279 & 0.4225 & 0.416 \\
HRM practices $\times$ OC & & -0.083 & & 0.118 \\
Adjusted R squared & 0.456 & 0.521 & 0.42 & 0.461 \\
p < 0.05 & & & & \\
\hline
\end{tabular}

\section{Discussion and Conclusion}

Investigating the relationship between HRM practices and OP and entering KM as a mediator as well as OC as a 
moderator in the relationship between these two constructs, the results show that HRM practices predict OP, either directly or indirectly through KM. In this regard, OC positively moderates the relationship between HRM practices and OP and negatively moderates the relationship between HRM practices and KM.

Regarding the positive impact of HRM practices on OP found in this study, similar results have been revealed in the literature (e.g. Amin et al., 2014; Chan \& Mak, 2012; Chand \& Katou, 2007; Moideenkutty et al., 2011; Osman et al., 2011). Inconsistently, Kuo (2011) found a non-significant direct relationship between HRM practices and OP. The positive association of HRM practices and KM was also asserted by Theriou and Chatzoglou (2014), Kuo (2011) and Donate and Guadamillas (2011). Furthermore, Shehata (2015), Gharakhani and Mousakhani (2012), Marqués and Simón (2011), Zack et al. (2009), Mills and Smith (2011) and Kuo (2011) confirmed the significant impact of KM on OP.

On the mediating role of KM in the relationship between HRM practices and OP and in accordance with the results of this study, Patil and Kant (2012) underscored the vital role of KM in the relationship between HRM practices and OP. In terms of the moderating effect of OC, Balthazard et al. (2006) concluded that a constructive culture has a positive effect on OP, while a defensive culture has a negative impact on OP. Tseng (2010) studied three types of OC: Clan, hierarchical and adhocratic. These cultural styles refer to warm, creative and structural organizational environments, respectively. Her findings indicated that a culture of adhocracy affects knowledge conversion and improves OP. Finally, Nold (2012) supported the hypothesis that a positive OC enables KM, which in turn affects OP. This study contributes to the literature on HRM, KM and OP, filling a considerable gap by exploring the relationships between 10 practices of HRM and 10 indicators of OP, with KM as a mediator and $\mathrm{OC}$ as a moderator in these relationships.

\section{Limitations and Future Research}

The response rate was the main limitation experienced, requiring extra effort to distribute additional questionnaires. In addition, this is a cross-sectional study and hence the results cannot be generalized to all manufacturing industries in Jordan. Further research should be conducted on the moderating role of different OC dimensions.

\section{References}

Abd Rahman, A., Ng, S., Sambasivan, M., \& Wong, F. (2013). Training and Organizational Effectiveness: Moderating Role of Knowledge Management Process. European Journal of Training and Development, 37(5), 472-488. http://dx.doi.org/10.1108/03090591311327295

Akhavan, P., Sanjaghi, M., Rezaeenour, J., \& Ojaghi, H. (2014). Examining the Relationships between Organizational Culture, Knowledge Management and Environmental Responsiveness Capability. The Journal of Information and Knowledge Management Systems, 44(2), 228-248. http://dx.doi.org/10.1108/VINE-07-2012-0026

Aladwan, K., Bhanugopan, R., \& Fish, A. (2014). Human Resource Management Practices among Frontline Employees in the Jordanian Organizations: Navigating through the Crossroads of Change and Challenge. International Journal of Commerce and Management, 24(1), 6-24. http://dx.doi.org/10.1108/IJCoMA-09-2011-0027

Al-Tit, Ahmad, A., \& Hunitie, M. (2015). The Mediating The Mediating Effect of Employee Engagement between Its Antecedents and Consequences. Journal of Management Research, 7(5), 47-62. http://dx.doi.org/10.5296/jmr.v7i5.8048

Al-Tit, Ahmad, A., \& Nakhleh, H. (2014). The Role of E-Marketing in the Development of Internet User Attitudes toward Tourist Sites in Saudi Arabia. Journal of Administrative and Economic Sciences, 7(2), 25-44.

Al-Tit, Ahmad, A. (2014). Integration of Human Resources Management Practices and Operations Management and Its Impact on the Productivity and Profitability of Jordanian Manufacturing Companies (Quantitative Approach). Unpublished Ph.D Dissertation, Lebanon: Jinan University. http://dx.doi.org/10.13140/RG.2.1.2027.5047

Amin, M., Ismail, W., Rasid, S., \& Selemani, R. (2014). The Impact of Human Resource Management Practices on Performance. The TQM Journal, 26(2), 125-142. http://dx.doi.org/10.1108/TQM-10-2011-0062

Anantatmula, V. (2010). Impact of Cultural Differences on Knowledge Management in Global Projects. VINE, 40(3/4), 239-253. http://dx.doi.org/10.1108/03055721011071377

Andreeva, T., \& Kianto, A. (2012). Does Knowledge Management Really Matter? Linking Knowledge Management Practices, Competitiveness and Economic Performance. Journal of Knowledge Management, 16(4), 617-636. http://dx.doi.org/10.1108/13673271211246185 
Balthazard, P., Cooke, R., \& Potter, R. (2006). Dysfunctional Culture, Dysfunctional Organization: Capturing the Behavioral Norms that form Organizational Culture and Drive Performance. Journal of Managerial Psychology, 21(8), 709-732. http://dx.doi.org/10.1108/02683940610713253

Cai, L., \& Kleiner, B. (2004). Effective Human Resource Management in Employment Agencies. Management Research News, 27(4/5), 91-98. http://dx.doi.org/10.1108/01409170410784518

Chan, S., \& Mak, W. (2012). High Performance Human Resource Practices and Organizational Performance: The Mediating Role of Occupational Safety and Health. Journal of Chinese Human Resources Management, 3(2), 136-150. http://dx.doi.org/10.1108/20408001211279238

Chand, M., \& Katou, A. (2007). The impact of HRM Practices on Organizational Performance in the Indian Hotel Industry. Employee Relations, 29(6), 576-594. http://dx.doi.org/10.1108/01425450710826096

Chang, C., \& Lin, T. (2015). The Role of Organizational Culture in the Knowledge Management Process. Journal of Knowledge Management, 19(3), 433-455. http://dx.doi.org/10.1108/JKM-08-2014-0353

Chiang, H., Han, T., \& Chuang, J. (2011). The Relationship between High-Commitment HRM and Knowledge-Sharing Behavior and Its Mediators. International Journal of Manpower, 32(5/6), 604-622. http://dx.doi.org/10.1108/01437721111158224

Chong, A., Chan, F., Ooi, K., \& Sim, J. (2011). Can Malaysian Firms Improve Organizational/ Innovation Performance Via SCM? Industrial Management \& Data Systems, 111(3), 410-431. http://dx.doi.org/10.1108/02635571111118288

Cooke, R. A., \& Lafferty, J. C. (1983). Level V: Organizational Culture Inventory (Form I). Plymouth, MI: Human Synergistics.

Corbett, L., \& Rastrick, K. (2000). Quality Performance and Organizational Culture. International Journal of Quality \& Reliability Management, 17(1), 14-26. http://dx.doi.org/10.1108/02656710010300126

Corbett, L., \& Rastrick, K. (2000). Quality Performance and Organizational Culture: A New Zealand Study. International Journal of Quality \& Reliability Management, 17(1), 14-26.

Darroch, J. (2005). Knowledge Management, Innovation and Firm Performance. Journal of Knowledge Management, 9(3), 101-115. http://dx.doi.org/10.1108/13673270510602809

Donate, M., \& Guadamillas, F. (2011). Organizational Factors to Support Knowledge Management and Innovation. Journal of Knowledge Management, 15(6), 890-914. http://dx.doi.org/10.1108/13673271111179271

Edvardsson, I. (2008). HRM and Knowledge Management. Employee Relations, 30(5), 553-561. http://dx.doi.org/10.1108/01425450810888303

Felíci, J., Caiado, E., \& Caiado, J. (2014). Human Capital, Social Capital and Organizational Performance. Management Decision, 52(2), 350-364. http://dx.doi.org/10.1108/MD-04-2013-0260

Felício, J. A., Couto, E., \& Caiado, J. (2014). Human Capital, Social Capital and Organizational Performance. Management Decision, 52(2), 350-364. http://dx.doi.org/10.1108/MD-04-2013-0260

Fong, C., Ooi, K., Lee, V., \& Chong, A. (2011). HRM Practices and Knowledge Sharing: An Empirical Study. International Journal of Manpower, 32(5/6), 704-723. http://dx.doi.org/10.1108/01437721111158288

Gharakhani, D., \& Mousakhani, M. (2012). Knowledge Management Capabilities and SMEs' Organizational Performance. Journal of Chinese Entrepreneurship, 4(1), 35-49. http://dx.doi.org/10.1108/17561391211200920

González, S. (2004). Improving Human Resources Management: Some Practical Questions and Answers. International Journal of Contemporary Hospitality Management, 16(1), 59-64. http://dx.doi.org/10.1108/09596110410516570

Hashim, J. (2010). Human Resource Management Practices on Organizational Commitment: The Islamic Perspective. Personnel Review, 39(6), 785-799. http://dx.doi.org/10.1108/00483481011075611

Ho, C. (2009). The Relationship between Knowledge Management Enablers and Performance. Industrial Management \& Data Systems, 109(1), 98-117. http://dx.doi.org/10.1108/02635570910926618

Ho, L. (2008). What Affects Organizational Performance?: The Linking of Learning and Knowledge Management. Industrial Management \& Data Systems, 108(9), 1234-1254. http://dx.doi.org/10.1108/02635570810914919

Hsiao, Y., Chen, C., \& Chang, S. (2011). Knowledge Management Capacity and Organizational Performance: The Social Interaction View. International Journal of Manpower, 32(5/6), 645-660. 
http://dx.doi.org/10.1108/01437721111158242

Inkinen, H., Kianto, A., \& Vanhala, M. (2015). Knowledge Management Practices and Innovation Performance in Finland. Baltic Journal of Management, 10(4). http://dx.doi.org/10.1108/BJM-10-2014-0178

Kalling, T. (2003). Knowledge Management and the Occasional Links with Performance. Journal of Knowledge Management, 7(3), 67-81. http://dx.doi.org/10.1108/13673270310485631

Kreitner, R., \& Kinicki, A. (2004). Organizational Behaviour, 6. New York: McGraw-Hill.

Kruger, C., \& Johnson, K. (2011). Is There A Correlation between Knowledge Management Maturity and Organizational Performance? VINE, 41(3), 265-295. http://dx.doi.org/10.1108/030557211111171618

Kuo, T. (2011). How to Improve Organizational Performance through Learning and Knowledge? International Journal of Manpower, 32(5/6), 581-603. http://dx.doi.org/10.1108/01437721111158215

Lee, S., \& Yu, K. (2004). Corporate Culture and Organizational Performance. Journal of Managerial Psychology, 19(4), 340-359. http://dx.doi.org/10.1108/02683940410537927

Lopez-Rodriguez, S. (2009). Environmental Engagement, Organizational Capability and Firm Performance. Corporate Governance: The International Journal of Business in Society, 9(4), 400-408. http://dx.doi.org/10.1108/14720700910984954

Maheshwari, S., \& Vohra, V. (2015). Identifying Critical HR Practices Impacting Employee Perception and Commitment During Organizational Change. Journal of Organizational Change Management, 28(5), 872-894. http://dx.doi.org/10.1108/JOCM-03-2014-0066

Mahmoudsalehi, M., \& Moradkhannejad, R. (2012). How Knowledge Management is Affected by Organizational Structure. The Learning Organization, 19(6), 518-528. http://dx.doi.org/10.1108/09696471211266974

Marqués, D., \& Simón, F. (2011). The Effect of Knowledge Management Practices on Firm Performance. Journal of Knowledge Management, 10(3), 143-156. http://dx.doi.org/10.1108/13673270610670911

Mills, A., \& Smith, T. (2011). Knowledge Management and Organizational Performance: A Decomposed View. Journal of Knowledge Management, 15(1), 156-171. http://dx.doi.org/10.1108/13673271111108756

Moideenkutty, U., Al-Lamki, A., \& Murthy, Y. (2011). HRM Practices and Organizational Performance in Oman. Personnel Review, 40(2), 239-251. http://dx.doi.org/10.1108/00483481111106101

Nold III, H. (2012). Linking Knowledge Processes with Firm Performance: Organizational Culture. Journal of Intellectual Capital, 13(1), 16-38. http://dx.doi.org/10.1108/14691931211196196

Ortega-Parra, A., \& Sastre-Castillo, M. (2013). Impact of Perceived Corporate Culture on Organizational commitment. Management Decision, 51(5), 1071-1083. http://dx.doi.org/10.1108/MD-08-2012-0599

Osman, I., Ho, T., \& Galang, M. (2011). The Relationship between Human Resource Practices and Firm Performance: An Empirical Assessment of Firms in Malaysia. Business Strategy Series, 12(1), 41-48. http://dx.doi.org/10.1108/17515631111100412

Park, H., Ribiére, V., \& Schulte, W. D. J. (2004), Critical Attributes of Organizational Culture that Promote Knowledge Management Technology Implementation Success. Journal of Knowledge Management, 8(3), 106-117. http://dx.doi.org/10.1108/13673270410541079

Patil, S., \& Kant, R. (2012). Organizational Culture a HR Strategy for Successful Knowledge Management. Strategic HR Review, 11(6), 322-328. http://dx.doi.org/10.1108/14754391211264785

Pyöriä, P. (2007). Informal Organizational Culture: The Foundation of knowledge Workers' Performance. Journal of Knowledge Management, 11(3), 16-30. http://dx.doi.org/10.1108/13673270710752081

Rai, R. (2011). Knowledge Management and Organizational Culture: A Theoretical Integrative Framework. Journal of Knowledge Management, 15(5), 779-801. http://dx.doi.org/10.1108/13673271111174320

Rowden, R. (2002). High Performance and Human Resource Characteristics of Successful Small Manufacturing and Processing Companies. Leadership \& Organization Development Journal, 23(2), 79-83. http://dx.doi.org/10.1108/01437730210419206

Salehzadeh, R., Pool, J., Lashaki, J., Dolati, H., \& Jamkhaneh, H. (2015). Studying the Effect of Spiritual Leadership on Organizational Performance: An Empirical Study in Hotel Industry. International Journal of Culture, Tourism and Hospitality Research, 9(3), 346-359. http://dx.doi.org/10.1108/IJCTHR-03-2015-0012

Sharabati, A., Jawad, S., \& Bontis, N. (2010). Intellectual Capital and Business Performance in the Pharmaceutical 
Sector of Jordan. Management Decision, 48(1), 105-131. http://dx.doi.org/10.1108/00251741011014481

Shehata, G. (2015). Leveraging Organizational Performance Via Knowledge Management Systems Platforms in Emerging Economies: Evidence from the Egyptian Information and Communication Technology (ICT) Industry. VINE, 45(2), 239-278. http://dx.doi.org/10.1108/VINE-06-2014-0045

Syed-Ikhsan, S., \& Rowland, F. (2004). Knowledge Management in a Public Organization: A Study on the Relationship between Organizational Elements and the Performance of Knowledge Transfer. Journal of Knowledge Management, 8(2), 95-111. http://dx.doi.org/10.1108/13673270410529145

Tan, C., \& Nasurdin, A. (2011). Human Resource Management Practices and Organizational Innovation: Assessing the Mediating Role of Knowledge Management Effectiveness. The Electronic Journal of Knowledge Management, 9(2), 155-167. Available online at www.ejkm.com.

Theriou, G., \& Chatzoglou, P. (2014). The Impact of Best HRM Practices on Performance-Identifying Enabling Factors. Employee Relations, 36 (5), 535-561. http://dx.doi.org/10.1108/ER-02-2013-0025

Theriou, J., \& Chatzoglou, P. (2008). Enhancing Performance through Best HRM Practices, Organizational Learning and Knowledge Management: A Conceptual Framework. European Business Review, 20(3), 185-207. http://dx.doi.org/10.1108/09555340810871400

Tong, J., \& Mitra, A. (2009). Chinese Cultural Influences on Knowledge Management Practice. Journal of Knowledge Management, 13(2), 49-62. http://dx.doi.org/10.1108/13673270910942691

Tseng, S., \& Lee, P. (2014). The Effect of Knowledge Management Capability and Dynamic Capability on Organizational Performance. Journal of Enterprise Information Management, 27(2), 158-179. http://dx.doi.org/10.1108/JEIM-05-2012-0025

Tseng, S. (2010). The Correlation between Organizational Culture and Knowledge Conversion on Corporate $\begin{array}{lllll}\text { Performance. Journal of } & \text { Knowledge }\end{array}$ http://dx.doi.org/10.1108/13673271011032409

Valmohammadi, C., \& Ahmadi, M. (2015). The Impact of Knowledge Management Practices on Organizational Performance: A Balanced Scorecard Approach. Journal of Enterprise Information Management, 28(1), 131-159. http://dx.doi.org/10.1108/JEIM-09-2013-0066

Wang, D., Su, Z., \& Yang, D. (2011). Organizational Culture and Knowledge Creation Capability. Journal of Knowledge Management, 15(3), 363-373. http://dx.doi.org/10.1108/13673271111137385

Wu, I., \& Chen, J. (2014). Knowledge Management Driven Firm Performance: The Roles of Business Process Capabilities and Organizational Learning. Journal of Knowledge Management, 18(6), 1141-1164. http://dx.doi.org/10.1108/JKM-05-2014-0192

Yiing, L., \& Bin Ahmad, K. (2009). The Moderating Effects of Organizational Culture on the Relationships between Leadership Behavior and Organizational Commitment and between Organizational Commitment and Job Satisfaction and Performance. Leadership \& Organization Development Journal, 30(1), 53-86. http://dx.doi.org/10.1108/01437730910927106

Zack, M., McKeen, J., \& Singh, S. (2009). Knowledge Management and Organizational Performance: An Exploratory Analysis. Journal of Knowledge Management, 13(6), 392-409. http://dx.doi.org/10.1108/13673270910997088

Zairi, M. (1998). Managing Human Resources in Healthcare: Learning from World Class Practices-Part II. Health Manpower Management, 24(2), 58-65. http://dx.doi.org/10.1108/09552069810200003

\section{Copyrights}

Copyright for this article is retained by the author(s), with first publication rights granted to the journal.

This is an open-access article distributed under the terms and conditions of the Creative Commons Attribution license (http://creativecommons.org/licenses/by/3.0/). 